\title{
TERREIRO DO MESTRE BONITO
}

Larissa Isidoro Serradela ${ }^{1}$

O Terreiro do Mestre Bonito é atualmente, um dos espaços rituais mais importantes para o "quilombo-indígena" Tiririca dos Crioulos, como ponto de memória e transmissão de conhecimento sobre a história de seu complexo ritual. Está localizado no município de Carnaubeira da Penha, sertão de Itaparica, no Estado de Pernambuco.

Contam que, no período de 1950 a 1989 foi um local de encontro e de grande circulação dos atuais indígenas Pankará e "negros da Tiririca", na realização de rituais chamados de toré, ocorridos nas celebrações de finais de ano e nas noites de fogueira. Atualmente compõe a proposta dos limites territoriais da Tiririca.

Após mais ou menos 20 anos sem comparecerem neste local, o terreiro do Mestre Bonito é revisitado com o processo de atualização das práticas rituais e educacionais, ocorridas a partir de 2010. Estas foram influenciadas pela relação com o Estado, pesquisadoras (es) e outros grupos étnicos, possibilitando estratégias políticas do grupo na luta por seus direitos. No dia em que estas imagens foram tiradas, em minha primeira visita a este local, crianças de 8 a 12 anos de idade foram nomeadas (por lideranças e entidades espirituais) liderançasmirins como cacique, pajé, caboclo(a)-mestre e contra-mestres, iniciando assim, processos de formação e colaboração social.

1 Bacharel em Artes Visuais (Centro Universitário Belas Artes SP); Mestre em Antropologia Social (PPGA da Universidade Federal da Paraíba/ UFPB). 

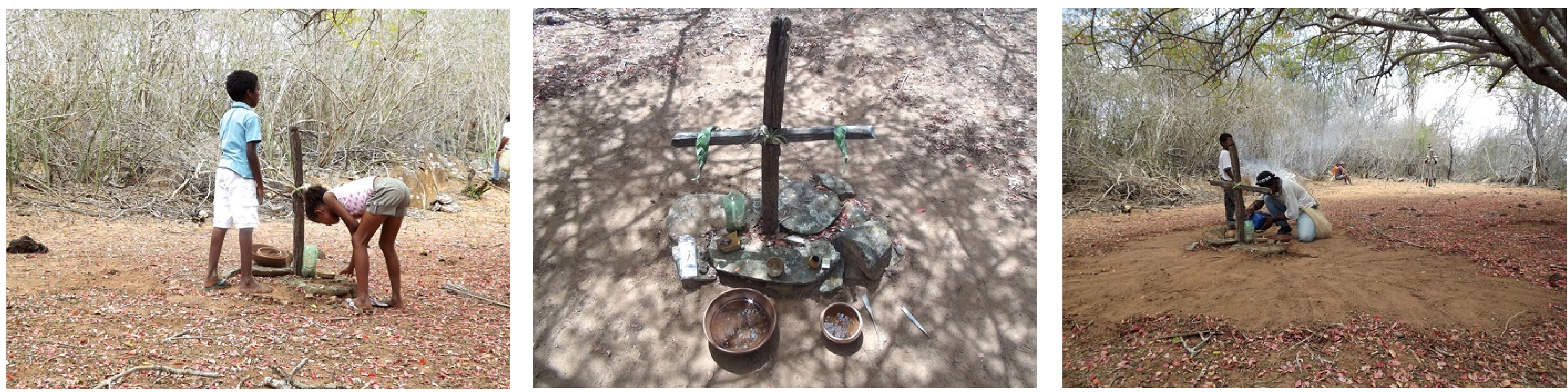

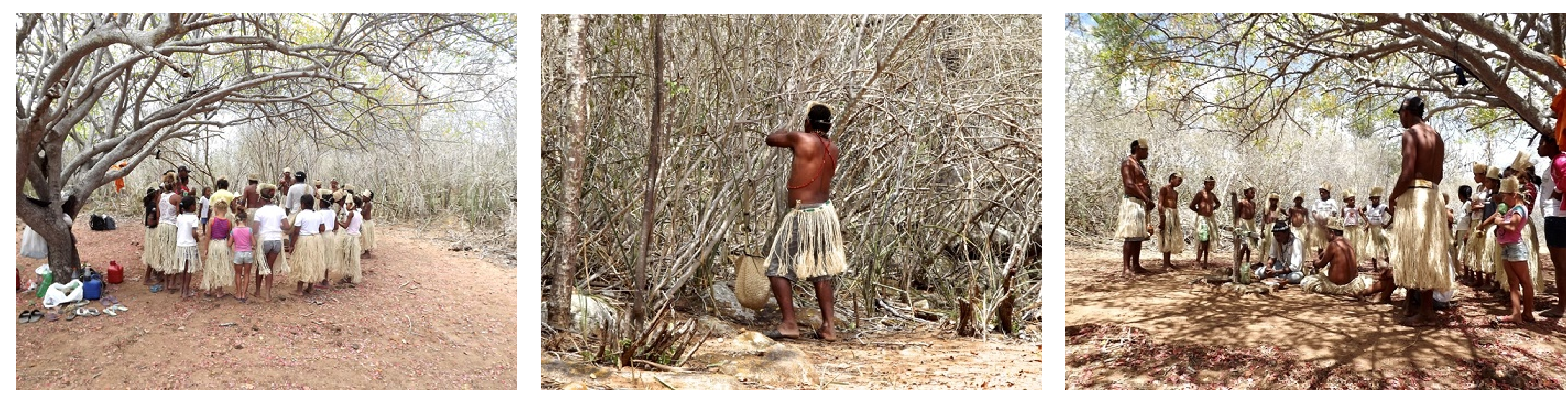